\title{
Mechanism of Action of Glucocorticosteroids \\ Inhibition of T Cell Proliferation and Interleukin 2 Production by Hydrocortisone is Reversed by Leukotriene $B_{4}$
}

James S. Goodwin, Durgaprasadarao Atluru, Stanislaw Sierakowski, and Elias A. Lianos

Department of Medicine, Medical College of Wisconsin, Milwaukee, Wisconsin 53226

\begin{abstract}
The mechanism whereby glucocorticosteroids are immunosuppressive is unknown. One potential mechanism of action of these compounds is inhibition of arachidonic acid metabolism. We found that the inhibition of lymphocyte proliferation by hydrocortisone or dexamethasone was mimicked by nonspecific lipoxygenase inhibitors and also by a specific 5-lipoxygenase inhibitor, but not by a specific cyclooxygenase inhibitor. Mitogen-stimulated cultures of $T$ cells produce $\sim 5 \times 10^{-9} \mathrm{M}$ leukotriene $B_{4}$ $\left(\mathrm{LTB}_{4}\right)$ in $\mathbf{2 4} \mathrm{h}$. This production of $\mathrm{LTB}_{4}$ is completely inhibited by concentrations of hydrocortisone or lipoxygenase inhibitors that inhibit mitogen-induced $\left[{ }^{3} \mathrm{H}\right]$ thymidine incorporation. The inhibition of lymphocyte proliferation by either hydrocortisone or by the 5-lipoxygenase inhibitor was totally reversed by LTB $_{4}$ but not by leukotriene $C_{4}$ or leukotriene $D_{4} . L^{2} B_{4}$ had no effect on the inhibition of lymphocyte proliferation by noncorticosteroids such as prostaglandin $E_{2}$, histamine, or $\boldsymbol{\gamma}$-interferon. The inhibition of interleukin 2 (IL-2) production by hydrocortisone or dexamethasone was also completely reversed by exogenous $\mathrm{LTB}_{4}$. LTB 4 alone did not cause IL-2 production or cell proliferation when added to resting lymphocytes. Thus, endogenous $\mathrm{LTB}_{4}$ production appears to be necessary but not sufficient for phytohemagglutinin-induced IL-2 production and lymphocyte proliferation. Glucocorticosteroids inhibit IL-2 production and lymphocyte proliferation by inhibiting endogenous $\mathrm{LTB}_{4}$ production.
\end{abstract}

\section{Introduction}

While the powerful effects of glucocorticosteroids (hereafter referred to as corticosteroids) on immune function have been recognized almost since their discovery in 1948, the mechanism of action of these drugs (or endogenous hormones) has been unclear. In 1975, Gryglewski et al. (1) and several other groups (24) showed that corticosteroids inhibit the release of arachidonic acid from membrane phospholipids and proposed that their antiinflammatory activity is due to this action. This hypothesis was difficult for many investigators to accept because it was already generally accepted that nonsteroidal antiinflammatory agents (NSAIA) ${ }^{1}$ work via inhibition of arachidonic acid metabolism,

Received for publication 4 April 1985 and in revised form 16 December 1985.

1. Abbreviations used in this paper: FCS, fetal calf serum; HETE, hydroxyeicosatetraenoic acid; HPLC, high performance liquid chromatography; IL-2, interleukin 2; $\mathrm{LTB}_{4}$, leukotriene $\mathrm{B}_{4} ; \mathrm{LTC}_{4}$, leukotriene $\mathrm{C}_{4}$;

J. Clin. Invest.

(c) The American Society for Clinical Investigation, Inc. 0021-9738/86/04/1244/07 \$1.00

Volume 77, April 1986, 1244-1250 and that the antiinflammatory effects of corticosteroids are clearly different and more powerful than those of NSAIA. The understanding of arachidonic acid metabolism at that time was essentially as a straight line synthetic pathway from membrane phospholipid to arachidonic acid to the prostaglandins. Thus, if corticosteroids and NSAIA inhibit at different points in the same pathway, they should have very similar actions. This problem was clarified when Samuelsson and others (5) identified the lipoxygenase metabolic pathways for arachidonic acid.

This more complex schema of arachidonic acid metabolism allows us to seriously consider the possibility that many of the pharmacologic and perhaps physiologic actions of corticosteroids are indeed via inhibition of arachidonic acid release from membrane phospholipid, because corticosteroids inhibit both cyclooxygenase and lipoxygenase products while NSAIA inhibit only cyclooxygenase products. Clearly, the evidence supporting this concept has grown considerably over the past few years. Danon and Assouline (6) showed that RNA and protein synthesis are required in order for steroids to inhibit prostaglandin production. In 1979 and 1980, Flower and his associates $(7,8)$ in England and Hirata, Axelrod, and their co-workers (9) at the National Institutes of Health identified a phospholipase $A_{2}$-inhibitory glycoprotein, termed macrocortin or lipomodulin, that is synthesized and released by cells upon exposure to corticosteroids. On the other hand, several investigators have failed to find an inhibition by corticosteroids of the endogenous production of arachidonic acid metabolites in vitro (10) and in vivo $(11,12)$.

In this paper we show that mitogen-stimulated $T$ cells produce substantial amounts of the 5-lipoxygenase product, leukotriene $\mathrm{B}_{4}\left(\mathrm{LTB}_{4}\right)$. Concentrations of hydrocortisone or dexamethasone which inhibit mitogen-induced $\left[{ }^{3} \mathrm{H}\right]$ thymidine in corporation and interleukin 2 (IL-2) synthesis also inhibit LTB production. In addition, nonspecific lipoxygenase inhibitors and a specific 5-lipoxygenase inhibitor also inhibit the mitogen response. Finally, readdition of $\mathrm{LTB}_{4}$ in concentrations normally produced to cultures containing hydrocortisone reverses the inhibition by hydrocortisone of IL-2 production and mitogen-induced proliferation of $\mathrm{T}$ cells. These findings support the concept that corticosteroids inhibit $T$ cell proliferation via phospholipase $\mathrm{A}_{2}$ inhibition; specifically, that corticosteroids inhibit mitogeninduced $T$ cell proliferation by suppressing endogenous $\mathrm{LTB}_{4}$ production.

\section{Methods}

Drugs. $\mathrm{LTB}_{4}$, leukotriene $\mathrm{C}_{4}\left(\mathrm{LTC}_{4}\right)$, and leukotriene $\mathrm{D}_{4}\left(\mathrm{LTD}_{4}\right)$ were kindly supplied by Dr. J. Rokach (Merck-Frosst Laboratories, Dorval,

$\mathrm{LTD}_{4}$, leukotriene $\mathrm{D}_{4} ;$ NDGA, nordihydroguaiaretic acid; NSAIA, nonsteroidal antiinflammatory agents; PHA, phytohemagglutinin; $\mathrm{PGE}_{2}$, prostaglandin $\mathrm{E}$. 
Canada). Various inhibitors of arachidonic acid metabolism and other drugs were examined for their effect on the mitogen response: indomethacin, nordihydroguaiaretic acid (NDGA) (13), hydrocortisone acetate, dexamethasone, histamine, prostaglandin $\mathrm{E}\left(\mathrm{PGE}_{2}\right)$ (all from Sigma Chemical Co., St. Louis, MO); BW755C (Wellcome Research Laboratories, Beckenham, England) (14); AA861 (Takeda Pharmaceutical, Osaka, Japan) $(15,16)$, and $\gamma$-interferon (Interferon Sciences, Inc., New Brunswick, NJ). The leukotrienes and drugs were dissolved in ethanol and appropriately diluted in RPMI 1640 medium immediately before use. This resulted in ethanol concentrations in the cultures of $10 \mathrm{mg} /$ $100 \mathrm{ml}$ to $1 \mu \mathrm{g} / 100 \mathrm{ml}$. Control cultures always contained appropriate amounts of ethanol, which had no measurable effect on the mitogen response.

Isolation of peripheral blood lymphocytes. Peripheral blood mononuclear cells were isolated on Ficoll-Hypaque density gradients (Pharmacia Fine Chemicals, Piscataway, NJ) from heparinized blood of healthy adult donors. Glass-adherent cells were removed by incubation at $37^{\circ} \mathrm{C}$ for $1 \mathrm{~h}$ on glass petri dishes in RPMI 1640 with $20 \%$ fetal calf serum (FCS). T cells were isolated from these nonadherent cells by rosetting with 2-aminoethylisothio-uranium bromide hydrobromide-treated sheep red blood cells followed by centrifugation over Ficoll-Hypaque for $\mathbf{3 0}$ min at $300 \mathrm{~g}$. The sheep red blood cells were lysed with Tris- $\mathrm{NHCl}$ buffer. The cell population, termed $\mathrm{T}$ cells, contained $95 \% \mathrm{~T}$ cells, as identified by the pan- $\mathrm{T}$ monoclonal reagent Leu- 5 , and $1-2 \%$ peroxidasepositive cells.

In some experiments the $T$ cells were exposed to 500 rads irradiation using a 2560 Maximar III, $250 \mathrm{KV}$ X-ray system (General Electric Co., Milwaukee, WI). After irradiation, cells were washed and resuspended in fresh medium for culture.

Cell cultures. The $T$ cells were cultured in microtiter plates, $10^{5}$ cells in $200 \mu \mathrm{l}$ of RPMI 1640 supplemented with L-glutamine, 10\% FCS, and penicillin-streptomycin. Phytohemagglutinin (PHA) and the drugs (arachidonic acid metabolites and inhibitors of arachidonic acid metabolism) were added directly to the wells upon initiation of cultures. Tritiated thymidine was added to cultures $64 \mathrm{~h}$ after addition of mitogens, and at $72 \mathrm{~h}$ the cells were harvested on filter paper and counted in a liquid scintillation counter. All cultures were performed in triplicate. Percentage inhibition caused by the various agents was calculated and results expressed as: percent inhibition $=1-(\mathrm{A}-\mathrm{C}) /(\mathrm{B}-\mathrm{C}) \times 100 \%$, where $\mathrm{A}$ is counts per minute in cultures with drugs, $B$ is counts per minute in cultures without drug, and $\mathrm{C}$ is counts per minute in nonstimulated cultures.

Measurement of $L T B_{4}$ production. Cultures of $\mathrm{T}$ cells, $10^{6}$ cells $/ \mathrm{ml}$, were established in $10 \times 75$-mm culture tubes (2054; Falcon Labware, Becton, Dickinson \& Co., Oxnard, CA) with or without sera. After 0 or $24 \mathrm{~h}$, culture media were harvested and processed for leukotriene extraction, high pressure liquid chromatographic separation, and quantification by radioimmunoassay (RIA). Media, $1 \mathrm{ml}$, were spiked with $1,800-2,000 \mathrm{cpm}$ of purified ${ }^{3} \mathrm{H}\left[\mathrm{LTB}_{4}\right]$ (specific gravity $32 \mathrm{Ci} / \mathrm{mmol}$ ) to calculate recoveries. In a first step, media were extracted using $0.5 \mathrm{vol}$ of isopropanol. They were then acidified with formic acid ( $5 \mathrm{M}$ to a pH of 3.0-3.5) and a second extraction was performed using $2.5 \mathrm{vol}$ of diethyl ether. After centrifugation and phase separation, the organic phase (isopropanol/diethyl ether) was removed and the aqueous was reextracted with 2.5 vol of diethyl ether. The organic phases were pooled, dried under a nitrogen stream, and reconstituted in $1 \mathrm{ml}$ of methanol/water (3:7). This final solution was filtered through $0.2 \mu \mathrm{m}$ filters and injected in a high pressure liquid chromatograph consisting of two solvent delivery modules (112; Beckman Instruments, Inc., Fullerton, CA), a gradient controller, and a reverse-phase $\mathrm{C}_{18} 5 \mu$ cartridge (Nova Pak; Waters Associates, Millipore Corp., Milford, MA) placed in a radial compression module (RCM-100; Waters Associates). Leukotrienes were detected at $280 \mathrm{~nm}$ using an in-line absorbance detector (Spectroflow 772; Kratos Analytical Instruments, Ramsey, NJ) interphased with an integrator/ printer plotter (SP 4270; Spectra-Physics Inc., Mountain View, CA). Elutions were performed at flow rates of $1 \mathrm{ml} / \mathrm{min}$. An initial isocratic phase $(15 \mathrm{~min})$ using methanol/water/acetic acid (65:35:0.02 vol/vol), pH 5.7, adjusted with concentrated ammonium hydroxide (solvent B), was followed by a progressive gradient to $100 \%$ methanol over $30 \mathrm{~min}$. $\mathrm{LTB}_{4}$ and hydroxyeicosatetraenoic acid (HETE) were eluted during the gradient phase, upon completion of which the column was reconstituted with solvent B for $15 \mathrm{~min}$. Elution fractions $(1 \mathrm{ml})$ were collected at 1 -min intervals and those corresponding to $\mathrm{LTB}_{4}$ eluates (retention time $24.72+0.12 \mathrm{~min}$ ) were dried under vacuum and reconstituted in 300 $\mu l$ of $0.01 \mathrm{M}$ phosphate buffer containing $0.1 \%$ bovine gamma globulin for subsequent quantification of $\mathrm{LTB}_{4}$ by RIA. Recoveries of ${ }^{3} \mathrm{H}\left[\mathrm{LTB}_{4}\right]$ added in the media before extraction and chromatographic separation were $85-90 \%$. The RIA employed (Amersham Corp., Arlington Heights, IL) (17) is sensitive to $12.5 \mathrm{pg} / \mathrm{ml}$ and has $0.1 \%$ cross reactivity with LTC $_{4}$, PGE $_{2}$, arachidonic acid, 5-hydroxyeicosatetraenoic acid (5-HETE), 11-HETE, and 15-HETE. It has $2 \%$ cross reactivity with 12-HETE and $3 \%$ cross reactivity with sterioisomers of $\mathrm{LTB}_{4}$. None of the drugs employed in these studies, except of course $\mathrm{LTB}_{4}$, interfered with the measurement of LTB in the radioimmunoassay when added directly to the assay.

Measurement of interleukin 2 production. For IL-2 production $10^{6}$ T cells were cultured at $37^{\circ} \mathrm{C}$ in $1 \mathrm{ml} \mathrm{RPMI}$ with $10 \%$ FCS in $12 \times 75-$ $\mathrm{mm}$ round bottom plastic culture tubes with mitogens and drugs as indicated above. At $48 \mathrm{~h}$ the culture supernates were collected and were dialyzed against 500 vol of phosphate-buffered saline for $48 \mathrm{~h}$ at $4^{\circ} \mathrm{C}$ with ten changes of dialysis fluid. The IL-2-dependent cells used were an HT-2 cell line of BALB/C origin (generously provided by Dr. C. W. Spellman, Cancer Research Center, University of New Mexico School of Medicine, Albuquerque, NM). The cell line was maintained in RPMI 1640 with $10 \%$ FCS and IL-2 at $60 \mu / \mathrm{ml}$.

HT-2 cells were harvested from petri dishes, washed, and adjusted to a concentration of $10^{5}$ cells/ml with RPMI 1640, $10 \%$ FCS, $2 \mathrm{mM}$ glutamine, and antibiotics. Cells were cultured in $100-\mu \mathrm{l}$ vol in microtiter plates in the presence of $100 \mu$ lof IL-2 containing supernates, or those supernates diluted with complete media. After $\left.22 \mathrm{~h} \mathrm{[}{ }^{3} \mathrm{H}\right]$ thymidine was added and at $26 \mathrm{~h}$ cells were harvested and counted in a liquid scintillation counter. All cultures were performed in triplicate. Results were compared with a standard curve generated by adding known amounts of purified IL-2 (Electro-Nucleonics Inc., Silver Spring, MD) to HT-2 cells. In experiments where the effect of corticosteroids, $\mathrm{LTB}_{4}$, or other drugs was assessed on IL-2 production, control cultures were established where those drugs were added at the end of the culture. This never had an effect on the estimate of IL-2 production.

\section{Results}

Table I presents the results of experiments examining the effect of hydrocortisone and a variety of inhibitors of arachidonic acid metabolism on $\left[{ }^{3} \mathrm{H}\right]$ thymidine incorporation into mitogenstimulated human T cells. As we (18) and others (19) have previously reported, hydrocortisone and dexamethasone in nearphysiologic concentrations cause significant inhibition of $\left[{ }^{3} \mathrm{H}\right]$ thymidine incorporation, while indomethacin (a cyclooxygenase inhibitor) actually enhances $\left[{ }^{3} \mathrm{H}\right]$ thymidine incorporation (20). BW755 and NDGA, which block both the cyclooxygenase and lipoxygenase pathways and therefore have an effect on arachidonic acid metabolism similar to hydrocortisone (13, 14) also inhibit $\left[{ }^{3} \mathrm{H}\right]$ thymidine incorporation. AA861, a relatively selective inhibitor of 5-lipoxygenase with less effect on cyclooxygenase or on other lipoxygenase enzymes $(15,16)$ also caused substantial inhibition of mitogenesis. This suggests that a 5-lipoxygenase metabolite is necessary for normal mitogen-induced proliferation of $\mathrm{T}$ cells to occur. It also indirectly suggests that the relevant action of hydrocortisone in inhibiting mitogenesis might be in preventing the synthesis of a 5-lipoxygenase product. Accordingly, we next tested the effect of the addition of various 5-lipoxygenase metabolites of arachidonic acid on the inhibition of mitogenesis by hydrocortisone. The results of experiments 
Table I. Effect of Corticosteroids and Other Inhibitors of Arachidonic Acid Metabolism on $\left[{ }^{3} H\right]$ Thymidine Incorporation of PHA-stimulated Human T Cells

\begin{tabular}{lcl}
\hline Drug & cpm (SEM) & $\begin{array}{l}\text { Percent change } \\
\text { (SEM) }\end{array}$ \\
\hline mol/liter & & \\
- & $27,581(3042)$ & - \\
Indomethacin $\left(10^{-6}\right)$ & $34,621(3968)^{*}$ & $+26(6)$ \\
Hydrocortisone $\left(10^{-5}\right)$ & $4,115(804)^{*}$ & $-86(5)$ \\
Hydrocortisone $\left(10^{-6}\right)$ & $4,072(1131)^{*}$ & $-85(6)$ \\
Dexamethasone $\left(10^{-6}\right)$ & $3,987(1401)^{*}$ & $-86(4)$ \\
BW755C $\left(10^{-5}\right)$ & $3,716(665)^{*}$ & $-87(6)$ \\
NDGA $\left(10^{-5}\right)$ & $2,129(473)^{*}$ & $-93(3)$ \\
AA861 $\left(10^{-5}\right)$ & $4,121(1282)^{*}$ & $-83(5)$ \\
\hline
\end{tabular}

Human erythrocyte rosette positive cells were isolated from peripheral blood and cultured for $72 \mathrm{~h}$ with $2.5 \mu \mathrm{g} / \mathrm{ml}$ PHA. The drugs were added at the initiation of the cultures. Several concentrations of each drug were employed, but only one concentration is shown in the table. For NDGA, BW755C, and AA861, the concentration shown in the table causes $>90 \%$ inhibition of 5 -lipoxygenase activity (see Table IV). None of the drugs affected cell viability as assessed by trypan blue exclusion at the end of the culture. Data are presented as the mean \pm SEM for experiments on six different subjects. All cultures were performed in triplicate. ${ }^{*}$ Significantly different from control with $P<0.01$ by paired $t$ test.

with two subjects are shown in Table II. $\mathrm{LTB}_{4}$ by itself caused a slight inhibition of the PHA response. More importantly, $\mathrm{LTB}_{4}$ in low concentrations $\left(10^{-9}\right.$ and $\left.10^{-10} \mathrm{M}\right)$ almost completely reversed the inhibition caused by hydrocortisone. In contrast, neither $\mathrm{LTC}_{4}$ nor $\mathrm{LTD}_{4}$ had an effect on the PHA response or on the hydrocortisone inhibition of that response. $\mathrm{LTC}_{4}$ and $\mathrm{LTD}_{4}$ were tested at many concentrations (only one is shown), all of which were ineffective. A summary of experiments on 10 individuals is shown in Fig. 1. Hydrocortisone at $10^{-6} \mathrm{M}$ caused an average of $72 \%$ inhibition of $\left[{ }^{3} \mathrm{H}\right]$ thymidine incorporation. Adding back various concentrations of $\mathrm{LTB}_{4}$ largely eliminated that inhibition, with $10^{-10} \mathrm{M} \mathrm{LTB}_{4}$ giving the optimal effect (3\% inhibition compared with control). Similar data was obtained when the PHA response was inhibited by AA861, with any of the three concentrations of $\mathrm{LTB}_{4}$ employed causing complete restoration of the response. Just as with inhibition by hydrocortisone in Table II, neither $\mathrm{LTC}_{4}$ nor $\mathrm{LTD}_{4}$ had any effect on the inhibition of $\left[{ }^{3} \mathrm{H}\right]$ thymidine incorporation by AA861 (data not shown).

Fig. 2 shows the effect of delaying $\mathrm{LTB}_{4}$ addition to PHAstimulated cultures containing hydrocortisone. Addition of $\mathrm{LTB}_{4}$ up to $8 \mathrm{~h}$ after initiation of the culture still resulted in complete reversal of the inhibition by hydrocortisone, while after $16 \mathrm{~h}$ of culture, addition of $\mathrm{LTB}_{4}$ had little effect on hydrocortisone inhibition. Also, when the cells were preincubated with hydrocortisone for $2 \mathrm{~h}$ and then washed, addition of $\mathrm{LTB}_{4}$ after the washing still reversed the inhibition caused by hydrocortisone (data not shown).

Table III shows data suggesting that the reversal of inhibition of $\mathrm{T}$ cell proliferation by $\mathrm{LTB}_{4}$ is specific for corticosteroids. $\mathrm{LTB}_{4}$ did not reverse inhibition of $\left[{ }^{3} \mathrm{H}\right]$ thymidine incorporation caused by $\mathrm{PGE}_{2}$, histamine, $\gamma$-interferon, or $\gamma$-irradiation; but did reverse the inhibition caused by hydrocortisone or dexamethasone.
Table II. Effect of Adding 5-Lipoxygenase Metabolites of Arachidonic Acid on the Inhibition of Mitogen-induced Proliferation by Hydrocortisone

\begin{tabular}{lllrr}
\hline $\begin{array}{l}\text { PHA } \\
(2.5 \text { ug/ml })\end{array}$ & Hydrocortisone & $\begin{array}{l}\text { Arachidonic acid } \\
\text { metabolite }\end{array}$ & Subject 1 & Subject 2 \\
\hline & & & $c p m$ & \multicolumn{1}{c}{$c p m$} \\
+ & - & - & 18,389 & 20,069 \\
+ & - & LTB $_{4} 10^{-10}$ & 15,672 & 17,788 \\
+ & - & LTB $_{4} 10^{-9}$ & 15,210 & 17,297 \\
+ & - & LTC $_{4} 10^{-9}$ & 18,140 & 20,247 \\
+ & - & LTD $_{4} 10^{-9}$ & 18,493 & 19,941 \\
+ & $10^{-7} \mathrm{M}$ & - & 10,391 & 14,401 \\
+ & $10^{-7} \mathrm{M}$ & $\mathrm{LTB}_{4} 10^{-10}$ & 16,476 & 19,617 \\
+ & $10^{-7} \mathrm{M}$ & $\mathrm{LTB}_{4} 10^{-9}$ & 17,526 & 18,507 \\
+ & $10^{-7} \mathrm{M}$ & $\mathrm{LTC}_{4} 10^{-9}$ & 10,240 & 13,970 \\
+ & $10^{-7} \mathrm{M}$ & $\mathrm{LTD}_{4} 10^{-9}$ & 10,174 & 14,472 \\
+ & $10^{-6} \mathrm{M}$ & - & 4,995 & 6,766 \\
+ & $10^{-6} \mathrm{M}$ & $\mathrm{LTB}_{4} 10^{-10}$ & 16,269 & 20,331 \\
+ & $10^{-6} \mathrm{M}$ & $\mathrm{LTB}_{4} 10^{-9}$ & 15,106 & 18,507 \\
+ & $10^{-6} \mathrm{M}$ & $\mathrm{LTC}_{4} 10^{-9}$ & 5,004 & 7,120 \\
+ & $10^{-6} \mathrm{M}$ & LTD $_{4} 10^{-9}$ & 4,874 & 6,720 \\
\hline & & & &
\end{tabular}

Results of experiments with two subjects are shown. The counts per minute given represent the mean of triplicate cultures. The standard deviation of the triplicate cultures was always within $\pm 10 \%$ of the mean counts per minute. In both subjects the addition of $\mathrm{LTB}_{4}$ alone caused a slight inhibition of PHA-stimulated $\left[{ }^{3} \mathrm{H}\right]$ thymidine incorporation, while both $10^{-7} \mathrm{M}$ and $10^{-6} \mathrm{M}$ hydrocortisone caused substantial inhibition. Strikingly, addition of $\mathrm{LTB}_{4}$ to the cultures containing hydrocortisone restored the counts per minute almost to control levels. $\mathrm{LTC}_{4}$ and $\mathrm{LTD}_{4}$ had essentially no effect in this system over a wide concentration range $\left(10^{-8}-10^{-12} \mathrm{M}\right.$; only the values for $10^{-9} \mathrm{M}$ are given).

The fact that exogenous $\mathrm{LTB}_{4}$ reversed the inhibition of mitogenesis caused by hydrocortisone or lipoxygenase inhibitors suggested that endogenous $\mathrm{LTB}_{4}$ production might be a necessary

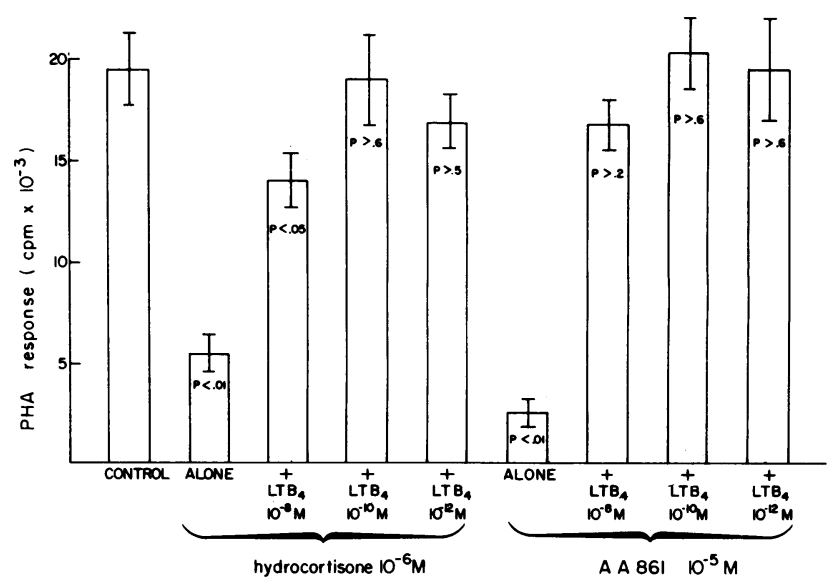

Figure 1. Effect of $\mathrm{LTB}_{4}$ on inhibition of PHA-stimulated $\left[{ }^{3} \mathrm{H}\right]$ thymidine incorporation by hydrocortisone or AA861. Data are expressed as the mean \pm SEM for experiments on 10 subjects. $P$ values are for paired $t$ tests comparing the counts per minute of the drugtreated cultures with the control responses. Both hydrocortisone and AA861 caused substantial $(>70 \%)$ inhibition of $\left[{ }^{3} \mathrm{H}\right]$ thymidine incorporation and this suppression was completely eliminated by $\mathbf{L T B}_{\mathbf{4}}$ at $10^{-10}$. 


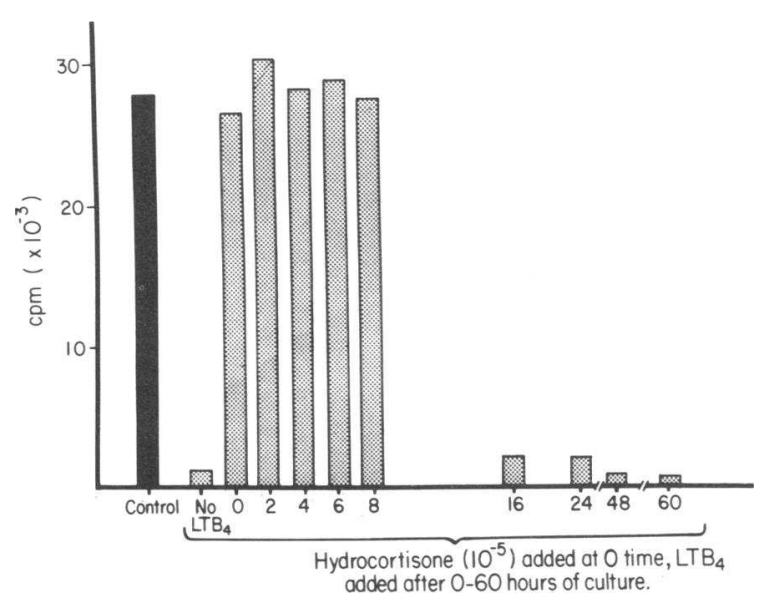

Figure 2. Effect of delaying addition of $\mathrm{LTB}_{4}$ for various times after culture initiation on reversal of hydrocortisone-induced inhibition of lymphocyte proliferation. Mean counts per minute from two experiments is shown. Hydrocortisone $\left(10^{-5} \mathrm{M}\right)$ caused $>90 \%$ inhibition of $\left[{ }^{3} \mathrm{H}\right]$ thymidine incorporation. This inhibition was completely reversed by addition of $\mathrm{LTB}_{4}\left(10^{-10} \mathrm{M}\right)$ at the beginning of the culture or 2,4 , 6 , or $8 \mathrm{~h}$ after beginning the culture. If $\mathrm{LTB}_{4}$ addition was delayed for $18 \mathrm{~h}$ or longer it had little or no effect on hydrocortisone inhibition of $\mathrm{T}$ cell proliferation.

component of mitogen-stimulated $\mathrm{T}$ cell proliferation. Accordingly, we measured $\mathrm{LTB}_{4}$ levels in these cultures.

Fig. 3 shows a representative high performance liquid chromatography (HPLC) analysis of the supernates of T cells cultured without $(A)$ or with $(B)$ PHA for $24 \mathrm{~h}$. In the supernates from the $\mathrm{T}$ cells cultured with PHA there was a large peak at the retention time comparable to $\mathrm{LTB}_{4}$. Elution fractions corresponding to this peak were collected and assayed for immunoreactive $\mathrm{LTB}_{4}$ using an RIA. These results are presented in Table IV and show that the $\mathrm{LTB}_{4}$ peak seen in Fig. 3 contained sub-

Table III. Lack of Effect of $\mathrm{LTB}_{4}$ on Inhibition of T Cell Proliferation Caused by Inhibitors Other Than Corticosteroids

\begin{tabular}{llll}
\hline Inhibitor & LTB $_{4}$ & Experiment 1 & Experiment 2 \\
\hline- & - & 23,057 & 22,294 \\
- & + & 17,778 & 16,342 \\
Hydrocortisone $\left(10^{-6}\right)$ & - & 13,600 & 14,293 \\
Hydrocortisone $\left(10^{-6}\right)$ & + & 20,724 & 22,296 \\
Dexamethasone $\left(10^{-6}\right)$ & - & 13,168 & 11,390 \\
Dexamethasone $\left(10^{-6}\right)$ & + & 21,188 & 20,105 \\
PGE $_{2}\left(10^{-6}\right)$ & - & 13,156 & 15,952 \\
PGE $_{2}\left(10^{-6}\right)$ & + & 11,377 & 17,686 \\
Histamine $\left(10^{-4}\right)$ & - & 12,444 & 12,976 \\
Histamine $\left(10^{-4}\right)$ & + & 11,945 & 14,618 \\
Interferon $(100 \mu / \mathrm{ml})$ & - & 14,350 & 13,824 \\
Interferon $(100 \mu / \mathrm{ml})$ & + & 13,931 & 14,682 \\
Irradiation $(500 \mathrm{rad})$ & + & 6,588 & 6,846 \\
Irradiation $(500 \mathrm{rad})$ & - & 7,146 & 7,747 \\
\hline
\end{tabular}

Results of experiments with two subjects are shown. Just as in Table II, $\operatorname{LTB}_{4}\left(10^{-10} \mathrm{M}\right)$ by itself caused a mild inhibition of $\left[{ }^{3} \mathrm{H}\right]$ thymidine incorporation, but reversed the greater degree of inhibition caused by hydrocortisone or dexamethasone. In contrast, $\mathbf{L T B}_{4}$ had essentially no effect on the inhibition of $\left[{ }^{3} \mathrm{H}\right]$ thymidine incorporation caused by $\mathrm{PGE}_{2}$, histamine, interferon, or $\gamma$-irradiation. All cultures contained PHA at $2.5 \mu \mathrm{g} / \mathrm{ml}$.
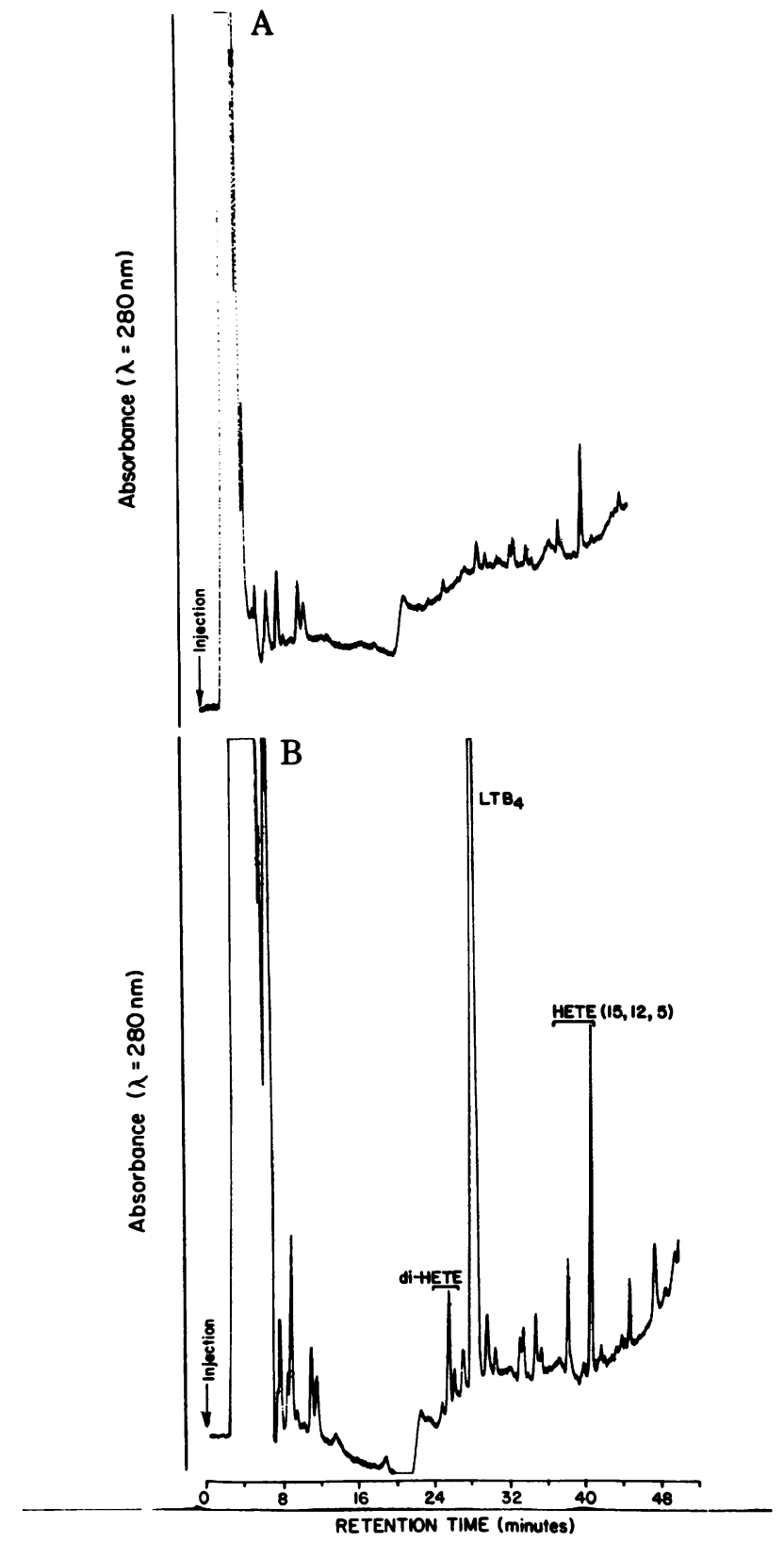

Figure 3. HPLC analysis of supernates of T cells cultured alone $(A)$ or with PHA $(B)$. The major peak in the supernate from the PHA-stimulated $T$ cell culture had a retention time identical to $\mathrm{LTB}_{4}$ and corresponded to the peak of immunoreactive $\mathrm{LTB}_{4}$ by RIA (see Table IV). There were additional smaller peaks with retention times identical to 12-HETE and 5-HETE in the HPLC analysis of the PHA-stimulated culture that were lacking in the control cultures.

stantial amounts of immunoreactive $\mathrm{LTB}_{4}$. The $1710 \mathrm{pg}$ of $\mathrm{LTB}_{4}$ produced by the $10^{6} \mathrm{~T}$ cells corresponds to an $\mathrm{LTB}_{4}$ concentration of $5 \times 10^{-9} \mathrm{M}$. No measurable $\mathrm{LTB}_{4}$ was produced by unstimulated T cells. Addition of hydrocortisone at $10^{-5}$ or $10^{-6}$ or of specific or nonspecific lipoxygenase inhibitors completely eliminated $\mathrm{LTB}_{4}$ production (Table IV) and inhibited by $>90 \%$ the production of other arachidonic acid metabolites (5-HETE, 12-HETE, and 15-HETE; data not shown). Hydrocortisone at $10^{-7}$ and $10^{-8} \mathrm{M}$ caused lesser inhibition of $\mathrm{LTB}_{4}$ production (Table IV). This parallels the less potent inhibition of lymphocyte proliferation by $10^{-7} \mathrm{M}$ hydrocortisone (Table II). 


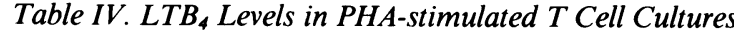

\begin{tabular}{lllll}
\hline Cells & PHA & $\begin{array}{l}\text { Duration } \\
\text { of culture }\end{array}$ & Drug & LTB \\
\hline & & $h$ & mol/liter & $p g / 10^{6}$ cells \\
& & & & $<100$ \\
T cells & - & 0 & - & $<100$ \\
+ & - & 24 & - & $<100$ \\
+ & + & 0 & - & $1710 \pm 160^{*}$ \\
+ & + & 24 & - & $<100$ \\
+ & + & 24 & hydrocortisone $\left(10^{-5}\right)$ & $<100$ \\
+ & + & 24 & hydrocortisone $\left(10^{-6}\right)$ & $<100+90^{*} \ddagger$ \\
+ & + & 24 & hydrocortisone $\left(10^{-7}\right)$ & $580+210^{*} \ddagger$ \\
+ & + & 24 & hydrocortisone $\left(10^{-8}\right)$ & $840+100$ \\
+ & + & 24 & NDGA $\left(10^{-5}\right)$ & $<100$ \\
+ & + & 24 & BW755C $\left(10^{-5}\right)$ & $<100$ \\
+ & + & 24 & AA861 $\left(10^{-5}\right)$ & $<100$ \\
& & & &
\end{tabular}

$10^{6} \mathrm{~T}$ cells were incubated in $1 \mathrm{ml}$ media with or without PHA $(2.5$ $\mu \mathrm{g} / \mathrm{ml}$ ). Cultures were harvested immediately or after $24 \mathrm{~h}$, and the supernates were removed and stored frozen for later analysis for LTB content. $\mathrm{LTB}_{4}$ concentration was determined by RIA of samples eluting with the retention of $\mathrm{LTB}_{4}$ after HPLC (see Methods). The data are given as picograms of $\mathrm{LTB}_{4}$ per $10^{6}$ cells; that is, per $1 \mathrm{ml}$ supernate of $10^{6}$ cells cultured in $1 \mathrm{ml}$ media. The $\mathrm{T}$ cell preparations contained $1-2 \%$ monocytes as identified by peroxidase staining and $>95 \%$ $T$ cells, as identified by erythrocyte rosetting and staining with pan- $T$ monoclonal reagents. Data represent the mean \pm SEM for four experiments on cells from different individuals.

* Different from cultures without PHA by paired $t$ test, $P<0.001$. $\ddagger$ Different from values of cells cultured with PHA without hydrocortisone, $P<0.01$ by paired $t$ tests.

Corticosteroids have been shown to inhibit IL-2 production, and exogenous IL-2 reverses the inhibition of mitogen-induced $\mathrm{T}$ cell proliferation by corticosteroids (46-49). To explore the relationship between $\mathrm{LTB}_{4}$ and IL-2, we examined the effect of hydrocortisone and $\mathrm{LTB}_{4}$ on IL-2 production by mitogen-stimulated T cells. As shown in Table V, inhibition of IL-2 production by hydrocortisone is reversed by exogenous $\mathrm{LTB}_{4}$. There is a clear dose-response relationship, with an effect as low as $10^{-14}$ M LTB 4 . PGE 2 or $\mathrm{LTC}_{4}$ did not affect the inhibition of IL-2 production by hydrocortisone.

\section{Discussion}

In order to conclude that the effects of corticosteroids in a given physiologic system are due to inhibition of arachidonic acid metabolism, several criteria should be met. First, one should demonstrate that corticosteroids do indeed inhibit arachidonic acid metabolism in the system under study. Second, one should be able to duplicate the effect of corticosteroids with drugs which inhibit all the metabolic pathways for arachidonic acid. If so, then it might also be possible to find a more specific inhibitor of arachidonic acid metabolism, such as a specific cyclooxygenase inhibitor or a specific inhibitor of one of the lipoxygenase enzymes, that duplicates the effects of corticosteroids in the physiologic system. Third, one should be able to reverse the effect of corticosteroids by adding back one or more specific arachidonic acid metabolites to the system, such as PGE, $\mathrm{LTC}_{4}$, 15-hydroperoxyeicosatetraenoic acid, etc.
Table V. Inhibition of IL-2 Production in Mitogen-stimulated Lymphocytes by Corticosteroids Is Reversed by LTB

\begin{tabular}{llll}
\hline & & $\begin{array}{l}\text { Arachidonic } \\
\text { acid metabolite }\end{array}$ & $\mathrm{IL}-2$ \\
\hline & & mol/liter & $\mathrm{U} / \mathrm{ml}$ \\
- & - & - & $<20$ \\
+ & - & - & $2,937 \pm 460^{*}$ \\
+ & Hydrocortisone $10^{-5} \mathrm{M}$ & - & $<20$ \\
+ & + & $\mathrm{LTB}_{4}\left(10^{-8}\right)$ & $4,384 \pm 842^{*}$ \\
+ & + & $\mathrm{LTB}_{4}\left(10^{-10}\right)$ & $2,840 \pm 52^{*} \ddagger$ \\
+ & + & $\mathrm{LTB}_{4}\left(10^{-12}\right)$ & $576 \pm 116^{*} \ddagger$ \\
+ & + & $\mathrm{LTB}_{4}\left(10^{-14}\right)$ & $212 \pm 45^{*} \ddagger$ \\
+ & + & $\mathrm{LTC}_{4}\left(10^{-8}\right)$ & $<20$ \\
+ & + & $\mathrm{PGE}_{2}\left(10^{-8}\right)$ & $<20$ \\
+ & Dexamethasone $10^{-5} \mathrm{M}$ & - & $<20$ \\
+ & + & $\mathrm{LTB}_{4}\left(10^{-10}\right)$ & $3,430 \pm 283^{*}$ \\
+ & AA861 & $10^{-5} \mathrm{M}$ & $<20$ \\
+ & + & $\mathrm{LTB}_{4}\left(10^{-10}\right)$ & $3,482 \pm 109^{*}$ \\
- & - & $\mathrm{LTB}_{4}\left(10^{-8}\right)$ & $<20$ \\
& & &
\end{tabular}

Data represent the mean \pm SEM from six experiments in different donors. $10^{6} \mathrm{~T}$ cells were cultured for $48 \mathrm{~h}$ in one $\mathrm{ml}$ media, and the supernates were dialyzed and assayed for IL-2 activity as described in the methods section.

* Different from cultures with PHA + hydrocortisone, $P<0.01$ by paired $t$ test.

$\ddagger$ Different from cultures with PHA + hydrocortisone, $+10^{-8} \mathrm{M}$, $\mathrm{LTB}_{4}, P<0.01$ by paired $t$ test.

In this present communication we found that, while exogenous $\mathrm{LTB}_{4}$ by itself caused slight inhibition of $\mathrm{T}$ cell proliferation, $\mathrm{LTB}_{4}$ added in the first $8 \mathrm{~h}$ of culture completely overcame the much more dramatic inhibition caused by hydrocortisone or dexamethasone. $\mathrm{LTB}_{4}$ is normally produced in mitogenstimulated $\mathrm{T}$ cell cultures and this production is completely inhibited by concentrations of hydrocortisone that inhibit $\left[{ }^{3} \mathrm{H}\right]$ thymidine incorporation. Other drugs that inhibit $\mathrm{LTB}_{4}$ production, such as specific and nonspecific lipoxygenase inhibitors, also inhibit the mitogen response, and exogenous $\mathrm{LTB}_{4}$ can reverse that inhibition. We conclude that endogenous $\mathrm{LTB}_{4}$ production early in the culture is necessary for mitogen-stimulated $T$ cell proliferation and that corticosteroids inhibit $T$ cell proliferation by reducing endogenous $\mathrm{LTB}_{4}$ production. Addition of $\mathrm{LTB}_{4}$ to mitogen-stimulated $\mathrm{T}$ cells cultured without hydrocortisone has little effect, presumably because there are already optimal levels of $\mathrm{LTB}_{4}$ produced endogenously.

$\mathrm{LTB}_{4}$ is produced by enzymatic hydrolysis of leukotriene $\mathrm{A}_{4}$ which is labile epoxide resulting from oxidation of arachidonic acid at the 5 position (5). $\mathrm{LTB}_{4}$ has powerful chemoattractant and aggregating properties for neutrophils $(21,22)$. There have been few reports suggesting a role for $\mathrm{LTB}_{4}$ in cellular immune responses. Several laboratories have reported modest (23-25) or no (26) inhibition of mitogen-stimulated proliferation of human T cells by $\mathrm{LTB}_{4}$ or by $\mathrm{LTC}_{4}(27)$. In addition, Rola-Plezczynski et al. (23) and we (28) have found that $\mathrm{LTB}_{4}$ causes induction of suppressor T cells. Several years ago Kelly et al. (29) reported that nonspecific lipoxygenase inhibitors such as NDGA inhibited mitogen-induced proliferation. Johnson and Torros (30) found that $\mathrm{LTB}_{4}, \mathrm{LTC}_{4}$, or $\mathrm{LTD}_{4}$ could replace the requirement for IL-2 for interferon production by murine splenocytes. In another 
study, we found that $\mathrm{LTB}_{4}$ can act synergistically with suboptimal levels of IL-2 in stimulating proliferation of IL-2 responsive cells (31).

While $\mathrm{LTB}_{4}$ has been identified as a major arachidonic acid metabolite of polymorphonuclear leukocytes (32), monocytemacrophages (33-35), basophils (36), and eosinophils (37), it has not been well accepted that purified $\mathrm{T}$ cells produce $\mathrm{LTB}_{4}$ or, indeed, any arachidonic acid metabolites $(35,38-42)$. Parker et al. (43) reported in 1979 that lymphocytes metabolized arachidonic acid to 5-HETE, but their lymphocyte preparations contained substantial numbers of monocytes and some neutrophils. Goetzl (44) reported that human T cells (E-rosette positive) stimulated with concanavalin A or a calcium ionophore produce substantial amounts of 5-lipoxygenase metabolites, including $\mathrm{LTB}_{4}$, but others have disputed this claim $(35,38,45)$, arguing that the $\mathrm{LTB}_{\mathbf{4}}$ produced comes from contaminating monocytes in the $T$ cell preparation. We view this as an unlikely explanation for our results for several reasons. First, $\mathrm{LTB}_{4}$ was produced only in conjunction with the T cell mitogen PHA and not by resting cells (Fig. 3 and Table IV). Second, the percentage of contaminating monocytes in our preparations was $<2 \%$; in further experiments (Atluru, D., E. Lianos, and J. S. Goodwin, manuscript submitted for publication) we found that adding back increasing numbers of monocytes to the $T$ cells, to a final concentration of $20 \%$ monocytes, did not increase the $\mathrm{LTB}_{4}$ produced upon PHA stimulation. We feel that previous efforts to determine if lymphocytes produce $\mathrm{LTB}_{4}$ may have failed because the investigators added high concentrations of exogenous arachidonic acid to their cell cultures (35). We have found that exogenous arachidonic acid from $10^{-5}$ to $10^{-9} \mathrm{M}$ inhibits $\mathrm{LTB}_{4}$ and 5-HETE production by PHA-stimulated T cells by $>90 \%$ (45a). Laclos and his colleagues (46) have recently reported a similar phenomenon of inhibition of 5-lipoxygenase in human neutrophils by exogenous arachidonic acid.

There is a seeming discrepancy between the amount of the $\mathrm{LTB}_{4}$ required to restore $\mathrm{T}$ cell proliferation or IL-2 production in cultures containing hydrocortisone (Fig. 1 and Table V) and the amount of the $\mathrm{LTB}_{4}$ production actually produced in the cultures not containing hydrocortisone (Table IV). Much more $\mathrm{LTB}_{4}$ is produced than would appear necessary to maintain IL2 production and $T$ cell proliferation. We feel part of this discrepancy is due to the fact that we measured $\mathrm{LTB}_{4}$ production at $18 \mathrm{~h}$, whereas the effect of endogenous $\mathrm{LTB}_{4}$ is early, at least within the first $8 \mathrm{~h}$ of culture, based on the data in Fig. 2. The early $\mathrm{LTB}_{4}$ production in the first minutes of the culture is below the sensitivity of our assay, but, by extrapolation, is presumably in the range $\left(10^{-10}-10^{-12} \mathrm{M}\right)$ that causes restoration of IL-2 production and $T$ cell proliferation when added to PHA-stimulated cultures containing hydrocortisone.

Corticosteroids have been shown to inhibit IL- 2 production, and exogenous IL-2 reverses the inhibition of mitogen-induced $\mathrm{T}$ cell proliferation by corticosteroids (47-50). Thus, either $\mathrm{LTB}_{4}$ or IL-2 reverses the inhibition of T cell proliferation caused by corticosteroids. As shown in Table V, exogenous $\mathrm{LTB}_{4}$ restores IL-2 production by PHA-stimulated T cells cultured with hydrocortisone. Thus, we conclude that in $\mathrm{T}$ cell proliferation, $\mathrm{LTB}_{4}$ production is a necessary step in IL-2 production. Corticosteroids, by inhibiting $\mathrm{LTB}_{4}$ production, also inhibit IL-2 production, resulting in decreased $\mathrm{T}$ cell proliferation. The effect of corticosteroids on $\mathrm{T}$ cell proliferation can be overcome by adding $\mathrm{LTB}_{4}$, thus restoring endogenous IL-2 production to normal, or by adding IL-2 directly. Our findings suggest that specific 5-lipoxygenase inhibitors or specific $\mathrm{LTB}_{4}$ antagonists might possess immunosuppressive properties similar to corticosteroids, while, because of their specificity, they might not share many of the other physiologic effects of corticosteroids.

\section{Acknowledgments}

We are grateful to Dr. Rokach of Merck-Frosst, Dorval, Canada for his generosity in supplying us with leukotrienes and to Dr. M. Nishikawa and his colleagues at Takeda Chemical Industries, Osaka, Japan for supplying the AA861.

This work was supported by grants AG01245-06, AM34672-01, and AM34793-01 from the United States Public Health Service, and by grant 312-12-03 from the American Heart Association.

\section{References}

1. Gryglewski, R. J., B. Panczenko, R. Korbut, L. Grodzinska, and A. Ocetkiewica. 1975. Corticosteroids inhibit prostaglandin release from perfused mesenteric blood vessels in rabbits. Prostaglandins. 10:343354.

2. Kantrowitz, F., D. R. Robinsin, M. B. McGuire, and L. Levin. 1975. Corticosteroids inhibit prostaglandin production by rheumatoid synovia. Nature (Lond.). 258:737-739.

3. Floman, Y., and U. Zor. 1976. Mechanism of steroid action in inflammation: inhibition of prostaglandin synthesis and release. Prostaglandins. 12:403-411.

4. Tashjian, A., E. Yoelkel, J. McDonough, and L. Levin. 1975. Hydrocortisone inhibits prostaglandin production by mouse fibrosarcoma cells. Nature (Lond.). 258:739-741.

5. Samuelsson, B. 1983. Leukotrienes: mediators of immediate hypersensitivity reactions and inflammation. Science (Wash. DC). 220: 568-578.

6. Danon, A., and G. Assouline. 1978. Inhibition of prostaglandin biosynthesis by corticosteroids requires RNA and protein synthesis. $\mathrm{Na}$ ture (Lond.). 273:552-553.

7. Flower, R. J., and G. J. Blackwell. 1978. Anti-inflammatory steroids induce biosynthesis of a phospholipase $\mathrm{A} 2$ inhibitor which prevents prostaglandin generation. Nature (Lond.). 278:456-458.

8. Blackwell, G. J., R. Carnuccio, M. Di Rose, R. J. Flower, L. Parente, and P. Perrico. 1980. Macrocortin: a polypeptide causing the anti-phospholipase effect of glucocorticoids. Nature (Lond.). 287:147-149.

9. Hirata, F., E. Schiffman, K. Yenkatasubramanian, D. Salomen, and J. Axelrod. 1980. A phospholipase A2 inhibitory protein in rabbit neutrophils induced by glucocorticoids. Proc. Natl. Acad. Sci. USA. 77: 2533-2538.

10. Chandrabose, K. A., E. G. Lapentina, C. J. Schmitges, M. I. Siegel, and P. Cuatrecasas. 1978. Action of corticosteroids in regulation of prostaglandin biosynthesis in cultured fibroblasts. Proc. Natl. Acad. Sci. USA. 75:214-217.

11. Gold, E. W., O. D. Fox, and P. R. Edgar. 1978. The effect of long term corticosteroid administration on lipid and prostaglandin levels. J. Steroid Biochem. 9:313-316.

12. Naray-Fejes-Toth, A., G. Fejes-Toth, C. Fischer, and J. C. Frolich. 1984. Effect of dexamethasone on in vivo prostanoid production in the rabbit. J. Clin. Invest. 74:120-123.

13. Hamberg, M. 1976. On the formation of thromboxane B2 and 12L-hydroxy-5,8, 10,14-eicosatetranoic acid (12 ho-20:4) in tissues from the guinea pig. Biochim. Biophys. Acta. 431:651-659.

14. Higgs, G. A., R. J. Flower, and J. R. Vane. 1979. A new approach to anti-inflammatory drugs. Biochem. Pharmacol. 28:1949-1958.

15. Yoshimoto, T., K. Yokoyama, K. Ochi, and S. Yamamoto. 1983. A selective inhibitor of arachidonate 5-lipoxygenase, AA861. In Perspectives in Prostaglandin Research. Y. Shiokawa, M. Katori, and Y. Mizughima, editors. Experta Medica, Amsterdam. 72-79.

16. Yoshimoto, T., C. Yokoyama, K. Ochi, S. Yamamoto, Y. Maki, Y. Ashida, S. Terao, and M. Sheraishi. 1982. 2,3,5-trimethyl-6 (12-hy- 
droxy-5, 10-dodecadiynyl)-1,4-benzoquinone (AA861). A selective inhibitor of the 5-lipoxygenase reaction and the biosynthesis of slow-reacting substance of anaphylaxis. Biochim. Biophys. Acta. 713:470-477.

17. Salmon, J. A., P. Simmons, and R. M. J. Palmer. 1982. A radioimmunoassay for leukotriene $\mathrm{B}_{4}$. Prostaglandins. 24:225-234.

18. Goodwin, J. S., R. P. Messner, and R. C. Williams. 1979. Inhibition of $\mathrm{T}$ cell mitogenesis: effect of mitogen dose. Cell. Immunol. 45: 303-309.

19. Robertson, A. J., J. H. Gibbs, R. C. Potts, R. A. Brown, M. Browning, and J. S. Beck. 1981. Dose-related depression of PHA-induced stimulation of human lymphocytes by hydrocortisone. J. Immunopharmacol. 3:21-29.

20. Goodwin, J. S., A. D. Bankhurst, and R. P. Messner. 1977. Inhibition of $\mathrm{T}$ cell mitogenesis by prostaglandins: existence of a prostaglandin producing suppressor cell. J. Exp. Med. 146:1719-1734.

21. Ford-Hutchinson, A. W., M. A. Bray, M. V. Doig, M. E. Shipley, and J. H. Smith. 1980. Leukotriene B: a potent chemokinetic and aggregating substance released from polymorphonuclear leukocytes. Nature (Lond.). 286:264-266.

22. Goetzl, E. J., L. L. Brindley, and D. W. Goldman. 1983. Enhancement of human neutrophil adherence by synthetic leukotriene constituents of the slow-reacting substance of anaphylaxis. Immunology. 50:35-44.

23. Rola-Plezczynski, M., P. Boreat, and P. Sirois. 1982. Leukotriene B4 induces human suppressor lymphocytes. Biochem. Biophys. Res. Commun. 198:1531-1537.

24. Payan, D. G., and E. J. Goetzl. 1983. Specific suppression of human $\mathrm{T}$ lymphocyte function by leukotrienes B4. J. Immunol. 131: 551-560.

25. Gualde, N., D. Atluru, and J. S. Goodwin. 1985. Effect of lipoxygenase metabolites of arachidonic acid on proliferation of human $\mathrm{T}$ cells and T cell subsets. J. Immunol. 134:1125-1129.

26. Guttery, J. E., A. Tilden, D. K. Herron, P. Gallagher, S. R. Bakers, and E. W. Ades. 1984. Leukotrienes $\left(\mathrm{LTB}_{4}\right.$ and $\left.\mathrm{LTD}_{4}\right)$ : In vitro effects on human lymphocyte proliferation and transformation. J. Clin. Lab. Immunol. 13:151-153.

27. Webb, D. R., I. Nowowiejski, C. Healy, and T. J. Rogers. 1982. Immunosuppressive properties of leukotriene $\mathrm{D}_{4}$ and $\mathrm{E}_{4}$ in vitro. Biochem. Biophys. Res. Commun. 104:1617-1623.

28. Atluru, D., and J. S. Goodwin. 1984. Control of polyclonal immunoglobulin production from human lymphocytes by leukotrienes. $J$. Clin. Invest. 74:1444-1451.

29. Kelly, J. P., M. C. Johnson, and C. W. Parker. 1979. Effect of inhibitors of arachidonic acid metabolism on mitogenesis in human lymphocytes. J. Immunol. 122:1563-1572.

30. Johnson, H. M., and B. A. Torres. 1984. Leukotrienes: positive signals for regulation of $\gamma$-interferon production. J. Immunol. 132:413422.

31. Atluru, D., and J. S. Goodwin. 1986. Leukotriene $B_{4}$ causes proliferation of interleukin-2 dependent $T$ cells in the presence of suboptimal levels of interleukin-2. Cell. Immunol. In press.

32. Borgeat, P., and B. Samuelsson. 1979. Arachidonic acid metabolism in polymorphonuclear leukocytes: effects of ionophore A23187. Proc. Natl. Acad. Sci. USA. 76:2148-2153.

33. Humes, J. L., S. Sadowski, M. Galavadge, M. Goldenberg, E. Subers, R. J. Bonney, and F. A. Kuehl. 1982. Evidence for two sources of arachidonic acid for oxidative metabolism by mouse peritoneal macrophages. J. Biol. Chem. 257:1591-1599.
34. Bray, M. A., A. W. Ford-Hutchinson, and M. J. H. Smith. 1981. In SRS-A and Leukotrienes. P. J. Piper, editor. Wiley, Chicester, West Sussex, United Kingdom. 253-265.

35. Goldyne, M. E., G. F. Burrish, P. Poubelle, and P. Borgeat. 1984. Arachidonic acid metabolism among human mononuclear leukocytes: lipoxygenase-related pathways. J. Biol. Chem. 259:8815-8819.

36. Levine, L. 1983. Inhibitions of the A-23187-stimulated leukotriene and prostaglandin biosynthesis of rat basophil leukemia cells by nonsteroidal anti-inflammatory drugs, anti-oxidants, and calcium blockers. Biochem. Pharmacol. 32:3023-3031.

37. Goetzl, E. J., P. F. Weller, and F. F. Sun. 1980. The regulation of human eosinophil function by endogenous mono-hydroxy-eicosatetranoic acids. J. Immunol. 124:926-935.

38. Goldyne, M. D. 1983. Eicosanoids and immunoregulation. Recent. Adv. Clin. Immunol. 3:9-21.

39. Dy, M., M. Astoin, M. Rigaud, and J. Hamburer. 1980. Prostaglandin release in the mixed lymphocyte culture: effect of pre-sensitization by a skin allograft; nature of the PG-producing cell. Eur. J. Immunol. 10:121-127.

40. Bray, M. A., R. G. Powell, and P. M. Lydyard. 1981. Prostaglandin generation by separated human blood mononuclear cell fractions. Int. J. Immunopharmacol. 3:377-383.

41. Kennedy, M. S., J. D. Stobo, and M. E. Goldyne. 1980. In vitro synthesis of prostaglandins and related lipids by populations of human peripheral blood mononuclear cells. Prostaglandins. 20:135-141.

42. Bankhurst, A. D., E. Hastain, J. S. Goodwin, and G. T. Peake. 1981. The nature of the prostaglandin-producing mononuclear cell in human peripheral blood. J. Lab. Clin. Med. 97:179-190.

43. Parker, C. W., W. F. Stenson, M. G. Huber, and J. P. Kelley. 1979. Formation of thromboxane $B_{2}$ and hydroxyarachidonic acids in purified human lymphocytes in the presence and absence of PHA. $J$. Immunol. 122:1572-1581.

44. Goetzl, E. J. 1981. Selective feedback inhibition of the 5-lipoxygenation of arachidonic acid in human T-lymphocytes. Biochem. Biophys. Res. Commun. 101:344-350.

45. Decker, D. M., and M. S. Kennedy. 1984. Arachidonic acid metabolism of the monocyte cell line U937. Clin. Res. 32:39 (Abstr.)

45a. Atluru, D., E. Lianos, and J. S. Goodwin. Arachidonic acid inhibits 5-lipoxygenase in human T cells. Biochem. Biophys. Res. Commun. In press.

46. Laclos, B. F., P. Braquet, and P. Borgeat. 1984. Characteristics of leukotrienes and hydroxyeicosatetranoic acid synthesis in human leukocytes: effect of arachidonic acid concentration. Prostaglandins Leukotrienes Med. 13:47-52.

47. Gillis, S., G. R. Crabtree, and K. A. Smith. 1979. Glucosteroid inhibition of $T$ cell growth factor production. J. Immunol. 123:16241632.

48. Arya, S. K., F. Wong-Staal, and R. C. Gallo. 1984. Dexamethasone-mediated inhibition of human cell growth factor and $\gamma$-interferon messenger RNA. Immunology. 133:273-280.

49. Randazzo, B., T. Hirschberg, and H. Hirschberg. 1984. Inhibition of the antigen-activated $\mathrm{T}$ cell response by methylprednisolone is caused by inhibition of interleukin-2 production. Int. J. Immunopharmacol. 6: 419-429.

50. Larsson, E. L. 1980. Cyclosporin A and dexamethasone suppress $T$ cell responses by selectively acting on distinct sites of the triggering process. J. Immunol. 124:2828-2833. 